\title{
Total RNA extraction from strawberry tree (Arbutus unedo) and several other woody- plants
}

\begin{abstract}
Zamboni A*, Pierantoni L, De Franceschi P
Studies of plant gene expression today need pure preparations of high-yielding undegraded RNA. This is not easily accomplished when working with plants and tissues like strawberry tree (Arbutus unedo) leaves that accumulate large amounts of polysaccharides and polyphenolic compounds, which co-purify with RNA. An improved leaf-tissue protocol developed for gene expression studies on Arbutus unedo yields for the first time a purity of RNA extract that makes possible CDNA synthesis and GPCR analysis in this plant species. When tested on material considered recalcitrant (leaves, roots, fruit flesh, fruit peel and styles from Pyrus communis, Prunus avium, Prunus persica and Cydonia oblonga), the method was able to extract RNA with good yield and high purity. This scalable, phenol-free, fast and easy-to-use RNA extraction protocol is effective on Arbutus unedo leaves as well as on awide range of different species and tissues, thus resulting particularly useful for gene expression analysis in nonmodel species for molecular biology.
\end{abstract}

Keywords: Arbutus unedo, RNA extraction, Roots, Styles, Woody plants, Fruits

\section{Introduction}

RNA extraction from specific plant organs and tissues is a preliminary step for many molecular studies in plant biology. However, isolation of high-quality RNA from some tissues is often difficult due to the high amounts of polyphenols, polysaccharides and other secondary metabolites they accumulate. These contaminants tend to co-purify and co-precipitate with the RNA in the presence of alcohols, thereby remaining in the final extracts and interfering with such downstream applications as cDNA synthesis, restriction endonuclease enzyme digestion and the establishment of cDNA libraries (Salzman et al. 1999). These problems often occur during RNA extraction from recalcitrant plants and, especially, from reserve-rich organs like fruits and seeds. In addition, the biosynthesis and accumulation of secondary metabolites in plants under biotic and abiotic stress, such as pathogen infection and drought, can be significantly enhanced

Department of Fruit Tree and Woody Plant Science, University of Bologna, via Fanin 42, Bologna (Italy)

${ }^{*}$ Corresponding Author: Alessandro Zamboni (a.zamboni@.unibo.it).

Received: Feb 18, 2008 - Accepted: Jun 27, 2008

Citation: Zamboni A, Pierantoni L, De Franceschi P, 2008. Total RNA extraction from strawberry tree (Arbutus unedo) and several other woody-plants. iForest 1 : 122-125 [online: 2008-08-27] URL: http://www.sisef.it/iforest
(Winkel-Shirley 2002, Chaves et al. 2003). While kits supplied by biotechnology companies extract RNA successfully from many tissues, they proved ineffective on tissues rich in polyphenols or polysaccharides (Kiefer et al. 2000).

Several protocols for RNA isolation from tissues of species with high contents of polyphenols or polysaccharides have been reported, including methods using soluble polyvinylpyrrolidone and ethanol precipitation (Salzman et al. 1999), hot borate (Wan \& Wilkins 1994), phenol extraction (Komjanc et al. 1999), calcium precipitation (Dal Cin et al. 2005), 2-butoxyethanol (Malnoy et al. 2001, Manning 1991) or cetyl trimethyl ammonium bromide (CTAB) in the extraction buffer (Meisel et al. 2005). We tested four of these protocols (Komjanc et al. 1999, Malnoy et al. 2001, Manning 1991, Meisel et al. 2005) and two commercially available RNA extraction kits to secure high-quality RNA in good amounts from an extremely recalcitrant plant such as strawberry tree $(\mathrm{Ar}$ butus unedo); the overall results proved unsatisfactory for all the methods, although the one described by Meisel et al. gave better results in terms of RNA purity compared with the others. We thus developed and tested a modified protocol that, through a simple optimization of some critical steps, allowed to achieve a great improvement in both RNA yield and purity when extracting from strawberry tree leaves. The effectiveness and versatility of this method was subsequently tested on different tissues (styles, fruit peel, fruit flesh, roots, leaves and seeds) from Pyrus communis, Prunus avium, Prunus persica and Cydonia oblonga, yielding in all cases adequate RNA amounts with a good purity grade.

\section{Materials and Methods}

\section{Plant material}

All plant materials used for RNA extraction were grown in the experimental fields of the Department of Fruit Tree and Woody Plant Sciences (Cadriano, Bologna, Italy). The tissues were completely differentiated and healthy. Pear tree styles were harvested immediately before bloom and fruit peel collected in the course of ripening. Year-old leaves were gathered from strawberry trees (evergreen) and the finest roots were collected from quince tree. Cherries were processed when commercially ripe for both seeds and fruit flesh, and adult leaves were collected from Peach.

\section{Solutions}

All solutions and reagents were prepared in diethylpyrocarbonate (DEPC)-treated water (Sambrook et al. 1989) and autoclaved. Tris$\mathrm{HCl}(\mathrm{pH} 8.0)$ was added to the appropriate solutions after autoclaving.

- Extraction buffer: 2\% (w/v) CTAB, 2\% (w/v) PVP (mol wt 40.000), 100 mM Tris$\mathrm{HCl}(\mathrm{pH} 8.0), 25 \mathrm{mM}$ EDTA, $2 \mathrm{M} \mathrm{NaCl}$, $0.05 \%$ spermidine trihydrochloride $(\mathrm{w} / \mathrm{v})$, 2\% B-mercaptoethanol (added just before use).

- Resuspension buffer: $1 \mathrm{M} \mathrm{NaCl}, 0.5 \%$ SDS, $10 \mathrm{mM}$ Tris HCL (pH 8.0), $1 \mathrm{mM}$ EDTA (pH 8.0)

- Chloroform:isoamyl alcohol (24:1 v:v)

- $8 \mathrm{M} \mathrm{LiCl}$

- Absolute Ethanol

\section{RNA extraction protocol}

Extraction buffer $(1 \mathrm{ml}$ per $100 \mathrm{mg}$ of $\mathrm{Ar}$ butus unedo leaves; see Tab. 2 for quantities used when extracting from other tissues) was pre-heated to $65^{\circ} \mathrm{C}$ in a water bath. Leaves were ground in liquid nitrogen by pestle and mortar and the frozen powder quickly transferred to the extraction buffer. The sample was mixed thoroughly and incubated at 65 ${ }^{\circ} \mathrm{C}$ for $15 \mathrm{~min}$, during the incubation the tube was vortexed 8-10 times to prevent the separation of tissue debris from extraction buffer.

An equal volume of chloroform:isoamyl alcohol (24:1 v:v) was added, the sample was vigorously vortexed and then centrifuged (15 $\mathrm{min}$ at $13000 \mathrm{~g}$ ). The supernatant was transferred to a new tube and the extraction with chloroform:isoamylalcohol (24:1 v:v) repeated.

The supernatant was carefully transferred to a new tube without disturbing the organic 
Tab. 1 - Yield and purity of RNA extracted from Arbutus unedo by different protocols. Extraction results of existing protocols on strawberry leaves. The method described in this study is presented with an intermediate developing step (I) and with the final protocol described in the Materials and methods section (II). See text for details. (A) Data represent mean and SE of 8 biological replicates; (B) Data represent mean and SE of 28 biological replicates; (C) Data represent mean and SE of 6 biological replicates; (D) Data represent mean and SE of 16 biological replicates; (E) Data represent mean and SE of 58 biological replicates.

\begin{tabular}{lccc}
\hline \multicolumn{1}{c}{ Methods } & $\begin{array}{c}\text { RNA yield } \\
(\boldsymbol{\mu g} / \mathbf{g} \text { FW) }\end{array}$ & $\begin{array}{c}\text { RNA Purity } \\
(\mathbf{A 2 6 0} / \mathbf{A 2 8 0})\end{array}$ & $\begin{array}{c}\text { RNA Purity } \\
(\mathbf{A 2 6 0} / \mathbf{A 2 3 0})\end{array}$ \\
\hline RNeasy Plant Mini Kit $^{\mathrm{TM}}$ Quiagen & 0 & n.d. & n.d. \\
SV Total RNA Isolation System $^{\mathrm{TM}}$, Promega & 0 & n.d. & n.d. \\
Komjanc et al. 1999 $^{\mathrm{A}}$ & $29 \pm 7$ & $0.8 \pm 0.2$ & $0.9 \pm 0.2$ \\
Manning 1991 $^{\mathrm{A}}$ & $27 \pm 12$ & $1.6 \pm 0.1$ & $0.8 \pm 0.1$ \\
Malnoy et al. 2001 $^{\mathrm{B}}$ & $49 \pm 18$ & $1.02 \pm 0.04$ & $0.5 \pm 0.1$ \\
Meisel et al. 2005 $^{\mathrm{C}}$ & $3 \pm 1$ & $1.6 \pm 0.1$ & $1.9 \pm 0.1$ \\
Method described in this study I $^{\mathrm{D}}$ & $18 \pm 4$ & $1.5 \pm 0.1$ & $1.9 \pm 0.1$ \\
Method described in this study II $^{\mathrm{E}}$ & $22 \pm 2$ & $1.86 \pm 0.04$ & $2.02 \pm 0.01$ \\
\hline
\end{tabular}

phase and one-third volumes of $8 \mathrm{M} \mathrm{LiCl}$ was added. The sample was mixed thoroughly by inverting the tube and incubated overnight at $0{ }^{\circ} \mathrm{C}$ (in ice).

RNA was pelleted by centrifuging the sample at $15500 \mathrm{~g}$ for $35 \mathrm{~min}$ and resuspended in $500 \mu \mathrm{l}$ of resuspension buffer. Samples were re-extracted with an equal volume of chloroform:isoamyl alcohol (24:1 $\mathrm{v}: \mathrm{v})$ to reduce residual contaminants; after centrifugation for $10 \mathrm{~min}$ at $15000 \mathrm{~g}$ the aqueous phase was recovered.

Two volumes of ice-cold $100 \%$ ethanol were added and RNA was precipitated at -80 ${ }^{\circ} \mathrm{C}$ for $30 \mathrm{~min}$. The sample was centrifuged at $17000 \mathrm{~g}$ for $20 \mathrm{~min}$ and the supernatant was removed. The pellet was air-dried at room temperature and then resuspended in 20-100 $\mu 1$ of DEPC-treated water.

Measurement of RNA yield and purity and downstream application

To prevent inaccurate quantification, the RNA pellet was slowly re-hydrated for 10 minutes on ice and mixed by inversion. The RNA yield was measured with a ND-1000 spectrophotometer (NanoDrop, Wilmington, Delaware USA) and the $260 / 280$ and $260 / 230$ absorption ratios were verified as quality indexes. The RNA was examined by electrophoresis on $1 \%$ agarose/TAE gels.

Total extracted RNA was treated with Turbo DNA-free (Ambion, Austin, USA) following the user's manual and then a control PCR was carried out with $0.2 \mu \mathrm{g}$ of total RNA in absence of reverse transcription in order to check for chromosomal DNA contamination. Samples that gave any amplification were purified a second time with DNase. Thereafter, $3 \mu \mathrm{g}$ of pure RNA were used with M-MLV Reverse Transcriptase (Invitrogen, Carlsbad, USA) and Oligo$(\mathrm{dT})_{20}$ or random primers for first strand cDNA synthesis following manufacturer's

\section{instruction}

The first-strand cDNA obtained and the primers for $18 \mathrm{~S}$ region (Forward: 5'-ACGGATCGCACGGCCTTCGTG-3' and reverse; 5'-ACCAGACTTGCCCTCCAATGG-3') were used to check the quality of the retrotranscription through PCR. The reaction was carried out in a MJ thermocycler using $20 \mu \mathrm{l}$ of Platinum Blue PCR SuperMix (Invitrogen), $1 \mu \mathrm{l}$ of reverse transcriptase mix and primers to a final concentration of 200 $\mathrm{nM}$. Cycles were programmed as follows: one initial denaturing cycle at $94{ }^{\circ} \mathrm{C}$ for 3 min, followed by 30 cycles of $30 \mathrm{~s}$ of denaturing at $94{ }^{\circ} \mathrm{C}, 30 \mathrm{~s}$ of annealing at $55^{\circ} \mathrm{C}$, and 1 min elongation at $72{ }^{\circ} \mathrm{C}$. The products were then loaded on agarose gel to verify amplification. Once verified, cDNA was used in a real time-PCR to quantify gene expression.

\section{Results and Discussion}

For successful isolation of pure, intact total RNA from Arbutus unedo, which is rich in polysaccharides compounds, it is important to prevent binding of these contaminants to nucleic acids. The success of an RNA isolation procedure thus depends on the quantity, quality and integrity of the recovered RNA (Suzuki et al. 2003). Four standard and improved methods for RNA isolation (Komjanc et al. 1999, Malnoy et al. 2001, Manning 1991, Meisel et al. 2005) and two commercially available RNA extraction kits (RNeasy Plant MiniKit ${ }^{\mathrm{TM}}$, Quiagen; SV Total RNA Isolation System ${ }^{\mathrm{TM}}$, Promega), were applied to Arbutus unedo leaves. While the two kits recovered no RNA (Tab. 1), a sufficient amount of RNA was obtained with the others (Komjanc et al. 1999, Malnoy et al. 2001, Manning 1991), but the purity was so low to make reverse transcription and successive gene expression analysis by real-time PCR impossible (Tab. 1).

Even the protocol reported by Meisel et al. (2005) proved inadequate. Although it extracted good quality RNA probably thanks to the CTAB in the extraction buffer, which dampens polysaccharide noise (Fang et al. 1992), its yield was very poor, thereby precluding single-leaf gene expression analysis (Tab. 1). Accordingly, we modified Meisel's protocol to improve RNA yield without losing the high quality of the extract. In fact, a technique improvement was essential to further molecular studies of a plant like strawberry tree.

Several critical steps that could affect the extraction yield and quality have been identified in the Meisel's protocol when applied to strawberry tree leaves. The ratio of sample fresh weight to extraction buffer, in particular, seems to play a crucial role. The first

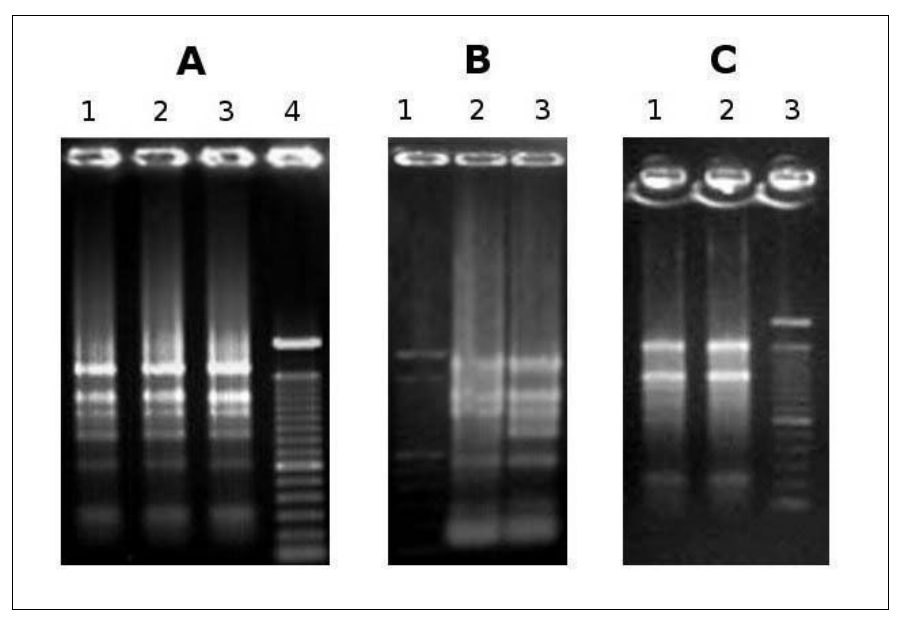

Fig. 1 - Agarose gel electrophoresis of RNA. Total RNA extracted from: (A) Cydonia $o b$ longa root (lane 1), Prunus avium fruit flesh (lane 2) and seed (lane 3), (B) Prunus persica (lane 2) and Arbutus unedo (lane 3) leaves, (C) Pyrus communis style (lane 1) and fruit peel (lane 2). The 28s rRNA band appears equal to or more abundant than the 18s rRNA band, thereby indicating that little or no RNA degradation occurred during extraction. 
Tab. 2 - Yield and purity of RNA extracted from different tissues. RNA extraction efficiency of the described protocol with tissues of several plant species. The weights of fresh tissue used for the extraction were around $20 \mathrm{mg}$ for styles, $1 \mathrm{~g}$ for fruit peels and for fruit flesh, $500 \mathrm{mg}$ for roots and for leaves and $50 \mathrm{mg}$ for seeds. (a) Data represent mean and SE of 21 biological replicates; (b) Data represent mean and SE of 8 biological replicates; (c) Data represent mean and $\mathrm{SE}$ of 3 biological replicates.

\begin{tabular}{|c|c|c|c|c|}
\hline \multirow{2}{*}{ Species } & \multirow{2}{*}{ Tissue } & RNA yield & RNA purity & RNA purity \\
\hline & & $(\mu \mathrm{g} / \mathrm{g} \mathbf{F W})$ & A260/A280 & $\mathbf{A 2 6 0 / A 2 3 0}$ \\
\hline Pyrus communis ${ }^{\text {a }}$ & Style & $268 \pm 40$ & $2.06 \pm 0.01$ & $2.25 \pm 0.03$ \\
\hline Pyrus communis ${ }^{\mathrm{b}}$ & Fruit peel & $7 \pm 1$ & $2.02 \pm 0.03$ & $1.9 \pm 0.1$ \\
\hline Prunus avium $^{\mathrm{c}}$ & Fruit flesh & $4.8 \pm 0.7$ & $2.09 \pm 0.02$ & $1.7 \pm 0.1$ \\
\hline Cydonia oblonga ${ }^{\mathrm{c}}$ & Root & $40 \pm 5$ & $2.04 \pm 0.02$ & $1.41 \pm 0.04$ \\
\hline Prunus persica $^{\mathrm{c}}$ & Leaf & $68 \pm 25$ & $2.07 \pm 0.06$ & $2.07 \pm 0.07$ \\
\hline Prunus avium $^{\mathrm{c}}$ & Seed & $101 \pm 14$ & $2.12 \pm 0.01$ & $2.19 \pm 0.01$ \\
\hline
\end{tabular}

yield improvement, which was from 3 to 18 $\mu \mathrm{g}$ RNA/g FW (see Tab. 1, "method described in this study I") was in fact achieved decreasing the quantity of starting fresh tissue from $2.5 \mathrm{~g}$ to $1 \mathrm{~g}$ per $1 \mathrm{ml}$ of extraction buffer, and raising the centrifuge speed to ensure a better separation of debris from the aqueous, RNA-containing phase.

Subsequently, a further optimization of extraction was obtained by further reducing the sample fresh weight to the final value of 100 mg per $1 \mathrm{ml}$ extraction buffer. Moreover, the lithium chloride $(\mathrm{LiCl})$ precipitation step was carried out in ice instead of at $4^{\circ} \mathrm{C}$; this seemed to assure a better precipitation efficiency and RNA integrity preservation These changes resulted both in a better yield (up to $21 \mu \mathrm{g} \mathrm{RNA} / \mathrm{gFW}$ ) and RNA purity, determined by A260/280 and A260/230 absorption ratios (see Tab. 1, "method described in this study II"; the complete protocol is described in the "Materials and methods" section). The RNA resulted intact after agarose gel electrophoresis (Fig. 1) and suitable for reverse transcription (Fig. 2) and

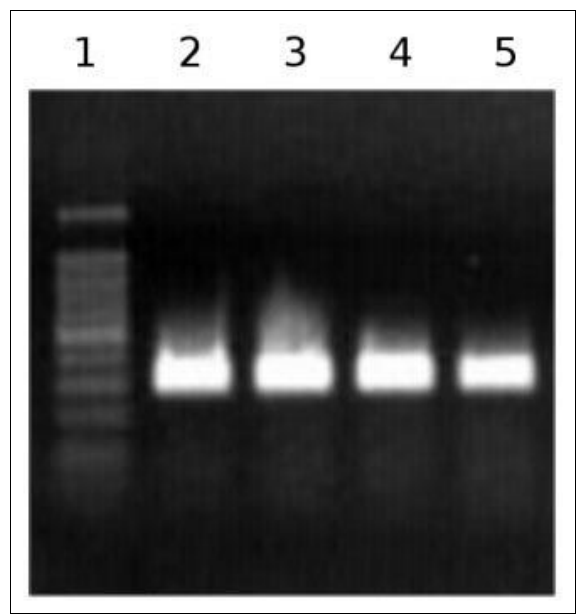

Fig. 2 - Agarose gel electrophoresis of PCR products. Partial 18S rRNA sequence amplification after retrotranscription from Arbutus unedo RNA. Lanes 2-5 are the products obtained from different RNA extracts. real time-PCR.

As noted above, plant tissues ranging from roots to fruit flesh of various woody species were then tested for the quality and yield of the RNA extracted. Although our protocol was originally developed for the particularly difficult plant tissues of Arbutus unedo leaves, it proved notably versatile for other species and tissues, resulting in high-quality RNA in all cases (see Fig. 1 and Tab. 2). As mentioned above, the weight of starting fresh material per $\mathrm{ml}$ of extraction buffer is a critical parameter that had to be adjusted in order to succeed in extracting RNA from strawberry tree leaves. However, when extracting from the other tested species and tissues, the method proved to be effective with a wide range of starting material amounts, giving good results from as little as $20 \mathrm{mg}$ of pear styles, and from $1 \mathrm{~g}$ of pear fruit peel or sweet cherry fruit flesh.

\section{Conclusions}

The small but significant changes we made to Meisel's protocol (Meisel et al. 2005) made possible to obtain a pure RNA extract from strawberry tree leaves while, to our knowledge, no other studies report RNA extraction from this plant. The development described improved extraction yield and purity while cutting extraction time.

Compared to other protocols developed for RNA extraction from recalcitrant species and/or tissues (Li \& Gray 1997, Sanchez \& Mariani 2002, Fils-Lycaon et al. 1996, MacLean et al. 1996, Birtic \& Kranner 2006, De Keukeleire et al. 2006, Le Provost et al. 2007, Fort et al. 2008, Wang et al. 2008), the presented method combines the advantages of being phenol-free, easily applicable to a wide range of tissues and not requiring expensive commercial kits.

Moreover, the varying amounts of starting material needed for different tissues (from $20 \mathrm{mg}$ of styles to $1 \mathrm{~g}$ of fruit flesh or peel) enabled testing of the protocol's scalability. Indeed, requiring only minor adjustments in labware and grinding because of material variability, our method also proved to be notably versatile and of good scalability, making it possibly the "preferred choice" for not expensive plant RNA extraction.

\section{List of abbreviations}

CTAB: cetyltrimethylammonium bromide; DEPC: diethylpyrocarbonate.

\section{Acknowledgements}

AZ performed the protocol elaboration, carried out the extractions from Arbutus unedo leaves and drafted the manuscript. LP carried out the extraction from Pyrus communis fruit peels, quince roots and cherry tree, helped to improve the protocol and participated in manuscript drafting. PDF carried out the extraction on Pyrus communis styles and participated to manuscript revision.

The authors thank Dr. G. Tonon for fruitful discussion and helpful assistance during protocol development, Dr. L. Dondini and Dr. S. Musacchi for helpful suggestions and practical support, Prof. Sansavini for encouragement and the availability of his lab and a special thanks to Anna for her strength.

\section{References}

Chaves MM, Maroco JP, Pereira JS (2003). Understanding plant responses to drought - from genes to the whole plant. Funct. Plant. Biol. 30: 239-264.

Birtic S, Kranner I (2006). Isolation of high-quality RNA from polyphenol-, polysaccharide- and lipid-rich seeds. Phytochem. Anal. 17 (3):144-148.

Dal Cin V, Danesin M, Rizzini FM, Ramina A (2005). RNA extraction from plant tissues: the use of calcium to precipitate contaminating pectic sugars. Mol. Biotechnol. 31 (2):113-119.

De Keukeleire J, Roldán-Ruiz I, Van Bockstaele E, Heyerick A, De Keukeleire D (2006). Efficient extraction of high-quality total RNA from various hop tissues (Humulus lupulus L.). Prep. Biochem. Biotechnol. 36 (4): 355-362.

Fang G, Hammar S, Rebecca R (1992). A quick and inexpensive method for removing polysaccharides from plant genomic DNA. Biotechniques 13:52-56.

Fils-Lycaon BR, Wiersma PA, Eastwell KC, Sautiere $P$ (1996). A cherry protein and its gene, abundantly expressed in ripening fruit, have been identified as thaumatin-like. Plant Physiol. 111: 269-273

Fort F, Hayoun L, Valls J, Canals JM, Arola L, Zamora F (2008). A new and simple method for rapid extraction and isolation of high-quality RNA from grape (Vitis vinifera) berries. J. Sci. Food Agric. 88: 179-184.

Kiefer E, Heller W, Ernst D (2000). A simple and efficient protocol for isolation of functional RNA from plant tissues rich in secondary metabolites. Plant Mol. Biol. Rep. 18: 33-39.

Komjanc M, Festi S, Rizzotti L, Cattivelli L, Cervone F, De Lorenzo G (1999). A leucine-rich repeat receptor-like protein kinase (LRPKm1) 
gene is induced in Malus $x$ domestica by Ven turia inaequalis infection and salicylic acid treatment. Plant Mol. Biol. 40: 945-957.

Le Provost G, Herrera R, Paiva JA, Chaumeil P, Salin F, Plomion C (2007). A micromethod for high throughput RNA extraction in forest trees. Biol. Res. 40 (3): 291-297.

Li H-Y, Gray JE (1997). Pollination-enhanced expression of a receptor-like protein kinase related gene in tobacco styles. Plant Mol. Biol. 33: 653-665.

MacLean DD, Murr DP, DeEll JR, Mackay AB, Kupferman EM (1996). Inhibition of PAL, CHS, and ERS1 in "Red d'Anjou" pear (Pyrus communis L.) by 1-MCP. Postharvest Biol. Technol. 45: 46-55.

Malnoy M, Reynoird JP, Mourgues F, Chevreau E, Simoneau P (2001). A method for isolating total RNA from pear leaves. Plant Mol. Biol.
Rep. 19: 69a-69f.

Manning K (1991). Isolation of nucleic acid from plants by differential solvent precipitation. Anal. Biochem. 195: 45-50.

Meisel L, Fonseca B, González S, Baezayates R, Cambiazo V, Campos R, Gonzalez M, Orellana A, Retamales J, Silva H (2005). A rapid and efficient method for purifying high quality total RNA from peaches (Prunus persica) for functional genomics analyses. Biol. Res. 38: 83-88.

Salzman RA, Fujita T, Zhu-Salzman K, Hasegawa PM, Bressan RA (1999). An improved RNA isolation method for plant tissues containing high levels of phenolic compounds or carbohydrates. Plant Mol. Biol. Rep. 17:11-17.

Sambrook J, Fitsch EF, Maniatis T (1989). Molecular cloning: a laboratory manual. Cold Spring Harbor Laboratory Press, Cold Spring Harbor, MA, USA.
Sanchez AM, Mariani C (2002). Expression of the ACC synthase and ACC oxidase coding genes after self-pollination and incongruous pollination of tobacco pistils. Plant Mol. Biol. 48: 351-359.

Suzuki Y, Hibino T, Kawazu T, Wada T, Kihara T, Koyama H (2003). Extraction of total RNA from leaves of eucalyptus and other woody and herbaceous plants using sodium isoascorbate. Biotechniques 34 (5): 988-990, 992-993.

Wan CY, Wilkins TA (1994). A modified hot borate method significantly enhances the yield of high-quality RNA from cotton (Gossypium hirsutum L.). Anal. Biochem. 233 (1): 7-12.

Wang X, Tian W, Li Y (2008). Development of an efficient protocol of RNA isolation from recalcitrant tree tissues. Mol. Biotechnol. 38 (1): 57-64.

Winkel-Shirley B (2002). Biosynthesis of flavonoids and effects of stress. Curr. Opinion Plant. Biol. 5: 218-223. 